DOI: $10.22616 /$ REEP.2019.035

\title{
Informal Professional Development of Higher Education Teachers in Kazakhstan
}

\author{
Gulsaule Kairat $^{1}$ M.Ed.; Dana Nurmukhanova ${ }^{2}$ M.Ed. \\ Eotvos Lorand University, Hungary \\ gulsaulek@gmail.com¹; dana.nurbatyr@gmail.com²
}

\begin{abstract}
Teacher professional development is a complex process, and this involves many processes, mechanisms, actions, and elements and it is difficult to specify exact outcomes in every instance. The aim of the study is to highlight the ways teachers perceive the essence of professional development and possible perspectives of an informal learning. The study is qualitative in nature by the usage of semi-structured interviews and involve four university teachers who currently work at different types of higher education institutions (HEI) in Kazakhstan. The results of this study show that formal professional development activities are happen to be the genesis of informal learning activities, as university teachers still refer the workplace learning being the basis of their informal learning. Formal and informal types of learning seem to be complementary as formal professional development activities create a need and provide a context for the use of new knowledge, and informal activities complete the gaps of on-going experience.
\end{abstract}

Keywords: professional development, higher education, informal professional learning.

\section{Introduction}

One of the main leading spheres of personal development, goal and sense of social realization and selfdevelopment of human being is the professional area of an individual. It's the one which comprises the main part of people's activities and we devote significant part of our whole life to it. To most of us professional sphere represents an opportunity to satisfy all range of needs, to discover abilities, to maintain ourselves as an individual, and to reach a particular social status. Thus, in the professional sphere a man can act as a self-actualizing individual and as a subject of self- esteem. In modern context the notion 'profession' is considered as a stable and relatively a wide variety of professional life which is a source of income, which provides a certain set of theoretical knowledge, practical experience and work skills and which is defined by the division of labour and its professional context as well; from the other hand, it's a huge group of people united by a common type of activity and working career. The aggregate of professions and their interrelation compose the professional structure of the society (Abbott, 2014).

Professional formation composes specific steps connected with significant psychophysiological and social-psychological peculiarities which provide successful performance of the professional activity (Vila, Germenji, 2016). Professional development of teachers is regarded as the most important part of their professional activity and there are a number of ways and opportunities that can be carried out in order to improve and enhance their knowledge and educational peculiarities. Professional development is identified "as activities that develop an individual's skills, knowledge, expertise and other characteristics as a teacher" (OECD, 2009). In order to make professional development efficient and effective for the teachers' content knowledge and pedagogical capacities, it's essential that professional development is "on-going, includes training, practice and feedback, and provides adequate time and follow-up support" (OECD, 2009). D. Richter and his colleagues defined professional development as an uptake of formal and informal learning opportunities that enhance and deepen teachers' skills and knowledge and other professional activities (Richter et al., 2011).

Teacher professional learning is a complex process (Baltusite, Katane, 2017) and "professional development is about teachers learning, learning how to learn, and transforming their knowledge into practice for the benefit of their students' growth" (Avalos, 2011, 10). This "involves many processes, mechanisms, actions, and elements and it is difficult to specify exact outcomes in every instance" (Opfer, Pedder, 2011, 379). The aim of the study is to highlight the ways teachers perceive the essence of professional development and possible perspectives of an informal learning.

\section{Methodology}

The general research question set in this study is: What are perceived opportunities of university teachers in informal professional learning? With the regard to the question we delved into the matter of how 
teachers recognize the essence of professional development and possible perspectives of an informal learning. We pinpointed the main activities teachers are involved for informal professional development and influencing aspects like workplace contexts. In order to find explanation to the research questions four university teachers were involved into this study who currently work at different types of higher education institutions in Kazakhstan.

In the interest of finding a profound answer to the main research question, qualitative research method, in particular, interview as means for data collection was used since interviews are regarded as one of the rich data sources (Creswell, 2012, 212).

For data collection, semi-structured interview with a set of questions was used. As B. Czarniawska pointed out in her study, "an interview is a common enterprise in knowledge production" where the interview process can be taken as a manipulated conversation, being "a rich source of knowledge about social practice insofar as they produce narratives" (Czarniawska, 2004, 47-50). Moreover, interviews, as claimed V.J. Janesick (2016), are one of the essential components of qualitative research in which rich and meaningful data can be elicited. Interviews help researchers in achieving and getting insight into respondents' perspectives (Hatch, 2002). The questions of the interview were formed so that to explore main areas of research (Table 1$)$.

Table 1

Interview questions

\begin{tabular}{|l|l|}
\hline \multicolumn{1}{|c|}{ Types of questions } & \multicolumn{1}{c|}{ Interview questions } \\
\hline $\begin{array}{l}\text { Information about a teacher's } \\
\text { background and experience. }\end{array}$ & General questions to start the interview and lead to the specifying questions \\
\hline $\begin{array}{l}\text { Questions for exploring the } \\
\text { ways of teachers' informal } \\
\text { learning }\end{array}$ & $\begin{array}{l}\text { Could you please describe how your first year of work in higher education } \\
\text { was? What was the most challenging part of it? How did you overcome it? } \\
\text { How do you feel about it now? } \\
\text { When do you have challenge at your work (for example, problem students) } \\
\text { what do you do? } \\
\text { Do you usually discuss your work issues with your colleagues and what } \\
\text { discouraged and motivated you to do that? }\end{array}$ \\
\hline $\begin{array}{l}\text { Questions on types of } \\
\text { informal learning }\end{array}$ & $\begin{array}{l}\text { Do you take extra activities for your professional learning using on-line } \\
\text { courses like Coursera, EdX, HaverdX? What are the biggest gains? } \\
\text { In your opinion, how online discussion groups or forums can be used for } \\
\text { your professional learning? } \\
\text { Do you find useful participating in conferences, seminars and } \\
\text { workshops? How do you transfer the knowledge acquired in these } \\
\text { activities for your professional learning? } \\
\text { Do you participate in networks referring to your profession? }\end{array}$ \\
\hline
\end{tabular}

As secondary source for the research the policy documents legislated in Kazakhstan were analysed: "Reviews of National Policies for Education: Higher Education in Kazakhstan" (OECD, 2007), "Law on Education of the Republic of Kazakhstan (with changes and additions in 2017) and "State Programme of Education Development for 2011-2020" (State Program of..., 2012).

The participants of the interviews work in different types of HEI: two teachers work in state universities, one - in a private and the other in a mixed type of university (partly state). We were interested in how these types of universities influence on teacher's professional development, and if there is any difference. The interviews with the university teachers were done via Skype due to time and place difference. With the respondents' consent the interviews were recorded. The participants were informed that the findings will be used only within this particular research project. After, the interviews were transcribed.

\section{Contextual framework}

Education is considered to be a key priority in "Kazakhstan - 2030" Strategy which seeks to find effective ways to adapt the educational system of the country to the conditions of labour economics. 
There are three main bases of State Policy in the field of higher education in Kazakhstan which are the Constitution of the Republic of Kazakhstan, the "Law on Education of the Republic of Kazakhstan" (Law on Education..., 2007), and "State Programme of Education Development for 2011-2020" (State Program of..., 2012) according to which higher education is open to those who have completed general secondary, technical and vocational education or further education.

"Law on Education of the Republic of Kazakhstan" (Law on Education..., 2007), first launched in 1999, is the core and primary law ensuring a general framework for higher education institutions in Kazakhstan to determine its strategy for development. In addition, this law strives to shape new national model for the country's educational system, and it presents principles of the State Policy in the field of education, in particular higher education.

"State Programme of Education Development for 2011-2020" developed by the Ministry of Education and Science aims to increase competitiveness of education and development of human capital through ensuring access to quality education for sustainable economic growth (State Program of..., 2012).

Higher education institutions in Kazakhstan are national research universities, national HEI, research universities, universities, academies or institutes. Conservatories, higher schools and higher colleges have a similar status.

According to its autonomy and state funding higher education institutions (HEI) can be classified into public (state), private and mixed universities. In accordance with the Law, state and public HEI are equal, however in some aspects of functioning these HEI possess definite level of autonomy. Both state and private universities independently hire workers (with the exception of appointing rectors/ heads for state universities), have right to establish international relations with national as well as international partners and conclude agreements on mutual cooperation and collaboration in different fields. In comparison with state universities private universities are characterised with more operational autonomy and demonstrate more flexible management. Whereas state universities have their own budget and right to control them in accordance with the parameters developed by the Ministry of Education and Science. One of the main differences is in salary of employees: salary and rewards are higher in private HEI.

For both types of HEI autonomy is not disseminated in respect of education programs, organization of education process, enrolment of students, awarding their own degrees. For instance, to create and develop new courses in state HEI permit is needed from the Ministry.

\section{Results and Discussion}

After analysing the transcriptions of the interviews, the following sub-categories emerged:

1. Teacher's perception of professional development (the meaning of the professional development).

2. The main activities in informal professional learning.

3. The possible influencing factors in informal professional learning.

One of the aims of the research is dedicated to the teachers' perception about informal learning in Higher education in Kazakhstan. Currently, the role of informal learning plays a pivotal role in teachers' workplace as well as in their life. The embodiment of it has a great impact in disseminating and advancing the diffusions of professional knowledge that gives the opportunity for them to affiliate with other colleagues and cultivate a huge emergence of knowledge accumulation in order that teachers could attain rationale end in their work. The meaning of informal learning for teachers is regarded as a fundamental and unique one because it is not included in the specific curriculum and is mostly not regulated by universities. Most teachers underpin informal learning but mostly the occurrence of the informal learning is caused by its being unconscious. But at the same time, various informal learning activities and factors can be faced that may have a great impact on teachers' professional development. One can encounter multitude of informal learning activities and factors that may be supportive and conducive for the beginning teachers as well as for experienced teachers.

The interview analysis with the university teachers reveals that the following activities are the main types of informal professional development of teachers in higher education. Regardless of the types of the universities (private or public), these activities are turned out to be common (Figure 1). 


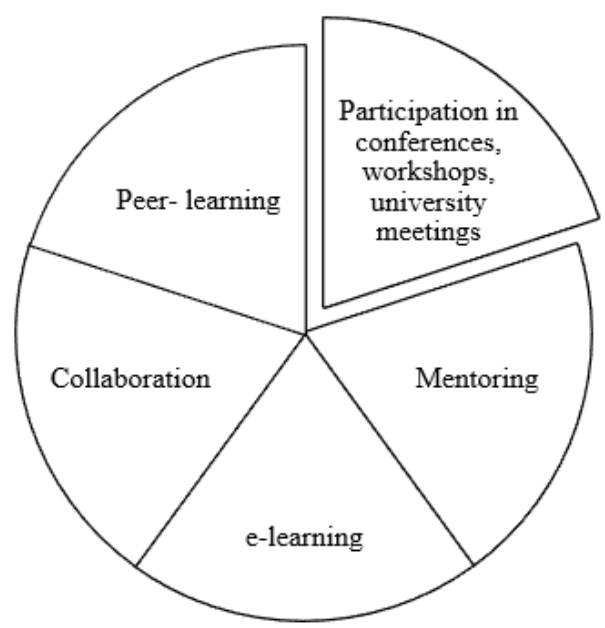

Figure 1. Informal professional development activities.

M. Patterson (2005) emphasizes that teaching in isolation is not supported in the field of education in the $21^{\text {st }}$ century. In this sense, all of the interviewees found collaboration, peer-learning and elements of mentoring to be beneficial and advantageous both for their personal and professional growth.

Mainly, the teachers learn from colleagues through professional discourse on the matters appearing in daily routine. One teacher noted, “...I had to plan not only my work in class but also students' individual work and their individual work with teacher, so in terms of this, I mean the volume of work, it was really tough, but today I feel like an expert on planning. So, I'm very thankful to my colleagues. They really helped me a lot at that time". Another described this informal learning: "Our staff are very united. Everyone can freely tell his or her opinion on some issue and we discuss it together and make decisions together". A third teacher commented, "...I sometimes can discuss any issues or problems with the teachers, they are always open to help me to give their opinions".

Learning new knowledge is most easily achieved with professional knowledge that is explicit, because it is easily expressed in words. Much professional knowledge, however, is tacit, that is, in the form of practical know-how that is not easily articulated, and so it is difficult to be aware of it. A knowledge audit is most easily conducted in a collaborative environment that encourages frequent professional talk and sharing among teachers. Informal learning happened primarily through face-to-face conversations among fellow teachers, as one of the teachers commented, “... the head of the chair and even doctors and professors who are already 65-70 years old are always glad to share their experience with novice teachers. Mostly, we, of course, interact with colleagues of the same age and discuss our problems, if they meet the same challenges and how they solve them".

Teachers informed mentoring activity as both beneficial and efficient. One teacher indicated: "I was very lucky to have excellent mentors who supported me a lot." Additionally, mentioning the role of general university meetings (in private universities) for collaborative solution of the emerged questions and problems being helpful in a way.

D. Laurillard $(2008,139)$ in her article argues that today "education has problems" and these problems can be solved with the help of technology through teachers. In considering the role of a teacher as a researcher the author says, "in the same way as researchers, academics are consummate reflective practitioners, able to respond to and contribute to rapid advances in their field, building on others' work, sharing ideas and results, moving forward collective knowledge and understanding" (Laurillard, 2008, 144).

Several teachers acknowledged the conferences, workshops and seminars are often an opportunity for learning: "these [conferences, workshops and seminars] are events where people share with their successful experiences, so you can really learn something new and useful from them and later you can even use it in your class. I always do so". Another teacher noted: “...it's very useful to participate in seminars and conferences because you can find a lot of new information for yourself, you can discuss a lot of problems... you can use activities used in conferences [workshops]... group works, pair works".

Despite the popularity of e-learning tools like Coursera (Coursera, 2019), EdX (EdX, 2019), HarverdX (HarverdX, 2019), not all the teachers reported using these tools for informal professional development, 
but instead indicated using resources from internet, like downloading books. One teacher shared: "I would choose books with free download as I think they are more helpful for me than all other stuff". Another teacher mentioned: “... because sometimes it's difficult to explain some new topics for students... it's useful for finding extra activities, extra information for students and for myself".

We live in a promptly changing world which logic of changes, in many respects, is defined by the development of information and communication technologies. It's characterized by an existence of an essential contradiction between generation of teachers and generation of students. The senior generation is needed to be retrained and adapt constantly to cardinally changing working conditions and life in general. Tendencies of the development of the society say that in the present world successful person is a person who is able to find quickly relevant information and effectively apply it to the solution of different tasks (Oliver, 2002; Sein, Harindranath, 2004; McFarlane, Sakellariou, 2002). One of the teachers admitted: "If I feel lack of some knowledge and if my colleagues can't prompt me, of course, I use the internet, different online courses or just YouTube, because there is a great amount of rather good content. If it's something very difficult there is also number of free or charged courses. So, in the cases of necessity of lacking knowledge, I use resources of the internet".

In Kazakhstan most of the beginner teachers of higher education institutions often encounter the challenges that are devoted to their educational process and organization, structure and administration of the university during first two or three years of their work. Such challenges embrace difficulties in lesson planning, paper work, work with problematic students, students' behaviour, mentoring for students, research and curriculum peculiarities, functional work of department, assessment criteria. One of the teachers emphasized: "I do not do any learning for now because I do not have any free time for this... a lot of time for filling all these papers, reports about the group, about the progress". While the other mentioned: "Now one of my tasks in my department is to be I am the one who is responsible for the students' exam papers, midterm exam papers, and the one who observe the other teacher. I think that another challenge is that most of the teachers are burnt out at their workplace. I am one of a few teachers who organized different kinds of events, conferences, meetings with students". The answers of the interviewees show that the main challenge that they face is the lack of time because of the paper routine and extra work that they do in the workplace.

The responses helped to identify the main factors that influence teachers' informal learning which can possibly influence teachers' learning and lead into the deterioration in teachers' professional development. The key factors are signified to be lack of time, teachers' burning out at their workplaces and teachers' overload works. These factors identified correspond with those presented in the theoretical part of the research. As the lack of time is considered to be the key factor and it is essential to show that according to the official documents of higher educational institutions (organizational charter of university, internal regulations of university) the university managements meet the requirements of regulatory legal acts, in particular, Education Law, Science Law and Labour Legislation of the Republic of Kazakhstan. For example, according to the Labour Legislation of the Republic of Kazakhstan, in internal regulations of university there are the definite amounts of obligatory hours that teachers should spend at their workplaces.

Additionally, it should be mentioned that there are other different kinds of factors impacting on teachers' informal learning such as family responsibilities, conducting educational guidance, participation and organization of events, duty in the dormitories (teachers attend the dormitories one by one to check students conditions and needs), mentoring (preparing portfolio for each students, filling different kinds of papers and detailed information about students), organization of mentoring hours with student groups, teachers' beliefs, personal interests, age, time, teaching experience and other social features.

\section{Conclusions}

Conscious movement to more successful indicators in teacher education is defined with the need in the professional development which is in turn is implemented in the following cases: awareness of teachers for the need of changes in teacher education; the availability of resources and readiness of the administration to support the initiatives of teachers; defining the goals and models for professional development; organization of feedbacks and support in case of the emergence of new challenges; the availability to make diagnosis of the results of professional development. 
It can be concluded that formal professional development activities are happen to be the genesis of these informal learning activities, as teachers still refer the workplace learning being the basis of their informal learning. Formal and informal types of learning seem to be complementary as formal professional development activities create a need and provide a context for the use of new knowledge, and informal activities complete the gaps of on-going experience.

Teachers in this study reported informal learning as a key component of their learning, especially the professional discourse they highly valued. The teachers noted that efficient use of time is crucial in this type of learning activity. They acknowledged the symbiotic relationship between formal and informal activities, but also noted the importance of a collaborative school culture as a critical basis for this informal mode of learning.

\section{Bibliography}

1. Abbott A. (2014). The system of professions: An essay on the division of expert labor. Chicago, IL: University of Chicago Press.

2. Avalos B. (2011). Teacher professional development in teaching and teacher education over ten years. Teaching and Teacher Education, 27(1), 10-20.

3. Baltusite R., Katane I. (2017). The Modern Teacher's Career. In V. Dišlere (Ed.), The Proceedings of the International Scientific Conference Rural. Environment. Education. Personality, 10. Jelgava: LLU TF, 30-39. Retrieved from http://llufb.llu.lv/conference/REEP/2017/Latvia-Univ-Agricult-REEP2017_proceedings-30-39.pdf

4. Creswell J.W. (2012). Educational research: planning, conducting, and evaluating quantitative and qualitative research. ( $4^{\text {th }}$ ed.). Boston, MA: Pearson Education Publishing.

5. Coursera. (2019). From courses to degrees. $100 \%$ online learning from the world's best universities and companies. Retrieved from https://www.coursera.org/

6. Czarniawska B. (2004). Narratives in social science research. Introducing Qualitative Methods. London: Sage Publications.

7. EdX. (2019). Free online courses from edX. Retrieved from https://www.edx.org/school/edx

8. HarverdX. (2019). Leading through learning. Retrieved from https://harvardx.harvard.edu/

9. Hatch J.A. (2002). Doing qualitative research in education settings. Albany, NY: State University of New York Press.

10. Janesick V.J. (2016). Stretching exercises for qualitative researchers. ( $4^{\text {th }}$ ed.). Thousand Oaks, CA: Sage Publications.

11. Laurillard D. (2008). The teacher as action researcher: Using technology to capture pedagogic form. Studies in Higher education, 33(2), 139-154.

12. Law on Education of the Republic of Kazakhstan. (2007). The official site of Ministry of Education and Science of RK. Retrieved from: https://iqaa.kz/images/Laws/Law_On_Education.eng.pdf

13. McFarlane A., Sakellariou S. (2002). The role of ICT in science education. Cambridge Journal of Education, 32(2), 219-232.

14. OECD. (2007). Reviews of National Policies for Education: Higher Education in Kazakhstan. Retrieved from

http://www.oecd.org/countries/kazakhstan/reviewsofnationalpoliciesforeducationhighereducationinkazakhstan.htm

15. OECD. (2009). Creating effective teaching and learning environments: first results from TALIS. Retrieved from https://www.oecd.org/education/school/43023606.pdf

16. Oliver R. (2002). The role of ICT in higher education for the 21 st century: ICT as a change agent for education. Retrieved from http://citeseerx.ist.psu.edu/viewdoc/download?doi=10.1.1.83.9509\&rep=rep1\&type=pdf

17. Opfer V.D., Pedder D. (2011). Conceptualizing teacher professional learning. Review of Educational Research, 81(3), 376-407.

18. Patterson M. (2005). Hazed! Educational Leadership, 62(8), 20-23.

19. Richter D., Kunter M., Klusmann U., Ludtke O., Baumert J. (2011). Professional development across the teaching career: Teachers' uptake of formal and informal learning opportunities. Teaching and Teacher Education: An International Journal of Research and Studies, 27(1), 116-126.

20. Sein M.K., Harindranath G. (2004). Conceptualizing the ICT artifact: Toward understanding the role of ICT in national development. The Information Society, 20(1), 15-24.

21. State Program of Education Development in the Republic of Kazakhstan for 2011-2020. (2012). Retrieved from http://planipolis.iiep.unesco.org/en/2012/state-program-education-development-republic-kazakhstan2011-2020-5506

22. Vila A., Germenji N. (2016). Teachers' standards. Primar Guide on Development of Teacher Professional Identity. 4(1), 149- 155. 